\title{
Ensino de Filosofia: método e recepção filosófica em Agnes Heller
}

\section{Philosophy Education: philosophical method and reception in Agnes Heller}

\author{
Geraldo Balduíno Horn ${ }^{1}$ \\ Ademir Aparecido Pinhelli Mendes ${ }^{2}$
}

\begin{abstract}
RESUMO
Este artigo apresenta, problematiza e analisa alguns pressupostos do método de recepção filosófica de Agnes Heller presentes em sua obra A Filosofia Radical. O conceito de recepção filosófica ocupa lugar central na análise. Mostra que não é possível pensar em educação filosófica senão a partir de uma epistemologia de referência circunscrita por um modus operandi filosófico. Daí decorre que só é possível conferir identidade e legitimidade à filosofia quando se reconhece e se estabelece uma "territorialidade epistemológica". Essa territorialidade se expressa por meio do estatuto de conhecimento propriamente filosófico, mas que se afirma como saber filosófico radical na medida em que não separa o conhecimento das condições humano-sociais de quem o tornou possível. Mais do que um conjunto de argumentos lógicos intelectivamente ordenados, conhecer com radicalidade tem a ver com atitude, com posicionamento que não separa o pensar do agir e da vida. A utopia racional, o carecimento, a atitude, a objetivação filosófica, são algumas das noções conceituais que possibilitam instituir e dar identidade ao Método filosófico, do modo como ele é compreendido e justificado por Heller.
\end{abstract}

Palavras-chave: Método filosófico; Filosofia Radical; recepção filosófica.

DOI: $10.1590 / 0104-4060.44746$

1 Universidade Federal do Paraná. Programa de Pós-Graduação em Educação. Curitiba, Paraná, Brasil. Rua General Carneiro, nº 460.CEP: 80060-150.E-mail: gbalduino.ufpr@gmail.com

2 Centro Universitário Internacional (Uninter). Escola Superior de Educação. Curitiba, Paraná, Brasil. Rua Treze de Maio, n ${ }^{\circ}$ 71. São Francisco. CEP: 80510-030. E-mail: pinhellimendes@gmail.com 


\begin{abstract}
This article presents and discusses some assumptions of Agnes Heller' philosophical receiving method in her work Radical Philosophy. The concept of philosophical reception occupies a central role in the analysis. It shows that one cannot think of philosophical education but from an epistemology of circumscribed reference by a philosophical modus operandi. Thus, it follows that one can only give identity and legitimacy to philosophy when an "epistemological territoriality" is recognized and established. This territoriality is expressed through the proper philosophical knowledge status which is stated as radical philosophical knowledge, considering that it does not separate knowledge from human-social conditions of those who made it possible. More than a set of logical arguments intellectually ordered, knowing radically has to do with attitude and a position that does not separate acting from thinking and life. Rational utopia, privation, attitude and philosophical objectification are some of the conceptual notions that enable to institute and give identity to the Philosophical method, the way it is understood and justified by Heller.
\end{abstract}

Keywords: Philosophical method; Radical Philosophy; philosophical reception.

\title{
Introdução
}

Este artigo apresenta, problematiza e analisa um escopo mais geral acerca do Método filosófico em Agnes Heller. Parte-se de uma explicitação dos pressupostos que instituem e dão legitimidade a uma das maneiras de se compreender o conhecimento filosófico a partir de uma perspectiva epistemológica-moral-radical no sentido como a autora concebe a construção do saber no horizonte próprio da filosofia.

No mais das vezes, as pesquisas em filosofia encontram forte ressonância e legitimação em objetos e problemas de pesquisa absolutamente delimitados em temas e problemas específicos presentes na História da Filosofia, perdendo, por vezes, seu caráter de universalidade e os critérios próprios da produção do conhecimento filosófico. Significa dizer que a produção filosófica acadêmica também é fortemente influenciada por critérios formais de cientificidade e legitimação, vale-se mais da reprodução de conceitos e ideias de filósofos e sistemas filosóficos que propriamente da busca de entendimentos dos grandes problemas humano-sociais que "incomodam" e comprometem a vida em sociedade. A produção acadêmica filosófica nos dias de hoje valoriza sobremaneira aquela 
filosofia que dá as costas aos problemas concretos da vida humana, preferindo manter o mundo entre parênteses que desafiá-lo a partir de um posicionamento filosoficamente assumido. Basta observar o que ocorre nos grandes eventos promovidos por entidades e instituições de filosofia. As reflexões sobre o Método filosófico em Heller que serão abordadas neste artigo decorrem também da problemática acima apresentada.

Os filósofos considerados e como tal reconhecidos e as chamadas academias filosóficas realizaram ao longo dos tempos verdadeiros diagnósticos de época. Não só o filósofo e seu pensamento eram inseparáveis entre si, como também de seu tempo. Esse é um dos traços essenciais do pensar filosófico que Heller recoloca ao refletir sobre a função social da filosofia. A filosofia só é filosofia enquanto expressão do pensar, do agir e do viver, simultaneamente. Só há recepção filosófica em sentido pleno quando esses elementos são considerados unitariamente, como parte da mesma operação, ou seja, da atitude filosófica.

\section{O pressuposto moral do método e da recepção filosófica}

A Filosofia Radical de Heller pode ser considerada uma filosofia moral ou, ao menos, como parte dela. Para efeitos do percurso que aqui assumimos, destacaremos três elementos - entre outros que podem ser depreendidos em sua obra - que justificam esse entendimento. Primeiro, por trata-se de uma filosofia inspirada e inscrita no modus operandi do filosofar grego: da filosofia política, da filosofia do sujeito social; do questionamento, do espanto e estranheza frente ao estabelecido como ponto de partida para a compreensão e ressignificação do sentido das coisas; do reconhecimento da função do logos na formação e emancipação do indivíduo no interior do mundo da polis. A polis como "território" da vida cotidiana, portanto, das contradições que demarcam os limites entre a adaptação social e as possibilidades de objetivação, entre o ser e o dever-ser, entre o sujeito particular e o homem-genérico. Como assevera Heller:

O Sócrates de Platão põe em ação praticamente todos os momentos dessa atitude. O ponto de partida é certamente o espanto (Thaumazein), que já contém o momento da desfetichização, pois significa simplesmente que se questiona o óbvio, mas que ele é aceito precisamente enquanto óbvio. (HELLER, 1983, p. 20). 
Segundo, porque só pode ser reconhecido como conhecimento filosófico aquele que expressa o sentido primeiro da filosofia baseado em dois momentos: "[...] o saber verdadeiro e o comportamento reto, bom; ou, em outras palavras, o Verdadeiro e o Bem." (HELLER, 1983, p. 14). Refere-se à estreita unidade entre Verdade e Bem, à busca do verdadeiro e do bem. Mas não se reduz a isso apenas

[...] a filosofia exige que seja posto em discussão tudo o que a própria razão não compreende [...] O "exercício da filosofia" significa: "vem pensar comigo, vamos conhecer a verdade juntos!" O filósofo guia o que pensa e o conduz através da argumentação para a clara luz do Verdadeiro e do Bem. (HELLER, 1983, p. 15-16).

Nada mais moralmente instituído do que esse entendimento. Infere e exige atitude de quem pensa e diz, uma vez que "pensar aí" encerra tensão entre ser e dever e a unidade do Verdadeiro e do Bem se dá no dever-ser. "O dever ser tem", na perspectiva da autora, “[...] o seu 'lugar topográfico', que na metafísica está 'no alto' ou nas 'profundezas': em algumas filosofias sociais, na instituição ideal.” (HELLER, 1983, p. 17).

Terceiro, porque a filosofia se realiza na e através da vida cotidiana e jamais fora dela. A cotidianidade está para a objetivação em Heller assim como a sociedade civil está para a sociedade política em Gramsci, a base econômica para a história em Marx. Trata-se do "lugar" das objetivações das capacidades humanas movidas por conflitos e atividades heterogêneas, múltiplas e particulares com vistas à homogeneização, à superação e ao aparecimento do sujeito livre e consciente. Vida cotidiana e ser humano são partes do mesmo "plano", por isso, confundem-se. Não há vida cotidiana sem ser humano inteiro. Constituem uma relação recíproca e necessária. Mutuamente determinante. Mesmo que aparentemente paradoxal, a cotidianidade é o ponto de partida e o ponto de chegada, isto é, fora dela nada acontece. Assim compreendida, a vida cotidiana é o "palco" da superação dos limites do indivíduo particular em direção às objetivações genéricas advindas da própria experiência social.

Depreende-se daí a existência de duas esferas fundamentais presentes na vida cotidiana a partir das quais Heller justifica a tensão entre o heterogêneo e o homogêneo, o ser e o dever-ser, o homem-particular e o homem-genérico. Trata-se da apreensão dos termos "em si" e "para-si". Para tanto, a autora fundamenta-se em Marx. O "em si" refere-se a tudo aquilo que ainda não foi modificado ou penetrado pela práxis, enquanto o "para-si”, ao contrário, corresponde àquilo que foi produzido ou transformado pela ação humana. 
Bittencourt Granjo (1996), ao analisar esse campo conceitual em Heller, afirma que a autora, ao lado dessas categorias,

[...] acrescenta o em-si social, formado por tudo o que o homem já encontra pronto ao nascer, ainda que fruto da atividade humana. Trata-se de um sistema de referências produzido pela estrutura unitária das objetivações genéricas em-si: utensílios e produtos, usos e linguagens. (BITTENCOURT GRANJO, 1996, p. 32).

Ao contrário das objetivações genéricas "em-si", que estão identificadas com a heterogeneidade, as objetivações genéricas "para-si" voltam-se à homogeneidade dando sentido e significado à própria vida humana uma vez que estão identificadas e são constituídas pelas artes, ciências, religiões e saberes filosóficos.

Pode-se depreender, portanto, que a compreensão teórica de Método filosófico em Heller é concebida e fundamentada numa perspectiva política e ético-moral a partir de categorias marxistas (mas, não somente). Para efeitos da análise aqui proposta acerca da recepção como método e vice-versa, tomaremos apenas duas noções conceituais que estão intrínseca e reciprocamente ligadas: o carecimento e o pensar com radicalidade. A primeira tem mais a ver com objetivação das necessidades humanas e a segunda com atitude filosófica. E, ambas com a constituição do humano-genérico em termos marxistas.

\section{Carecimento e pensar com radicalidade}

Toda filosofia que se pretende radical parte também de questionamentos profundamente radicais, ou seja: como devo pensar, como devo agir e como devo viver? Isso significa dizer que pensar, agir e viver constituem o verso e o reverso da mesma moeda. A unidade desses elementos por sua vez só é possível a partir da assunção do indivíduo como ser social, ontologicamente social. Pensar é um ato não só de imersão que o cotidiano exige - considerando o lugar social do sujeito - mas muito mais é uma responsabilidade cívica assumida pelo ser pensante tanto em relação a si como em relação aos outros. Isso porque não se trata de um "livre pensar" sem "eira nem beira" e sim de um pensar que se realiza enquanto imanência, enquanto objetivação. 
A Filosofia Radical não é para Heller (1983) um puro ato do pensamento que elabora e pensa, senão a realização de um carecimento. Nesse caso não há filosofia sem realização, portanto, sem objetivação. Uma filosofia que pensa e elabora a partir das necessidades imediatas e mediatas da existência humana. Nas palavras da própria autora: "Toda esfera de objetivação satisfaz um carecimento qualquer. [...] E, dado que a filosofia (como a arte, a teoria científica e, em parte, a religião) constitui um sistema de objetivações autônomo, em si concluído". (HELLER, 1983, p. 13). A satisfação do carecimento ocorre para ela sob a forma de recepção. Pode-se afirmar que a satisfação de carecimentos é o mesmo que dizer objetivação de necessidades humanas e isso ela afirma com base na concepção marxiana, em contraposição à perspectiva filosófica especulativa, uma vez que a superação da filosofia especulativa, de fato, só acontece quando ela se realiza como prática social - práxis.

A filosofia “[ [...] exige que o mundo se torne a pátria da humanidade. [...] A filosofia radical deve tornar-se filosofia de movimentos radicais, deve 'penetrar nas massas', 'tornar-se força material', para poder dizer um dia: pois bem, aconteceu". (HELLER, 1983, p. 139). Conceber assim implica necessariamente assumir o sentido marxiano de Filosofia Radical que, em última instância, significa tomar as coisas, os acontecimentos pela raiz. No entanto, não de qualquer forma, só é radical quando tomarmos a "raiz das coisas" como sendo o próprio homem. É aí que ocorre o encontro entre filosofia e humano. O humano está para a filosofia, assim como o racional está para o humano, isto é, "[...] a filosofia pressupõe que cada homem seja um ser racional". (HELLER, 1983, p. 142). Por isso ela dirige-se a todos os homens e convida-os "[...] vem, vamos pensar em conjunto, queremos buscar juntos a verdade". (HELLER, 1983, p. 142).

Buscar a verdade juntos, além de sugerir um espírito democrático à filosofia, também remete a um carecimento, qual seja, de possibilitar a todo ser humano desenvolver suas capacidades de ser-humano-genérico. Isto é, de ter não só acesso aos bens culturais, mas de produzir cultura e elevar seu pensamento ao nível filosófico. Não há nada mais classicamente grego e iluminista que essa aspiração. É também expressão de um carecimento radical que é ao mesmo tempo conhecimento das possibilidades e possibilidades de conhecimentos que possam orientar suas ações. Mas isso não é suficiente para concretizar a filosofia como utopia racional. Como assevera Heller (1983):

[...] não é racional uma filosofia que não aplica seus próprios valores ao âmbito de uma teoria da sociedade, que não assume a tarefa de tomar em consideração de tematizar as condições empíricas de realização da utopia racional. [...] não pode ser filosofia radical se permanecer apenas 
filosofia; deve ser também teoria da sociedade, teoria crítica da sociedade. (HELLER, 1983, p. 150).

Além dos pressupostos considerados até aqui, as tarefas fundamentais da Filosofia Radical podem ser, de acordo com Heller (1983), assim apresentadas:

a) A filosofia deve assumir-se como tal: como crítica ao dado, como essencialmente maiêutica, portanto, antítese à forma de vida existente ao modelo social atualmente predominante - o capitalismo; é de sua função social ser capaz de elaborar uma teoria crítica da sociedade:

[...] a filosofia radical deve criticar a sociedade fundada em relações de subordinação e de domínio; deve substituir a forma de vida que lhe é própria por uma nova. Sua crítica deve ser total: e sua utopia deve ser elaborada de modo a poder ser alcançada somente através de uma revolução social total. (HELLER, 1983, p. 152).

Isso significa dizer que a filosofia apresenta a possibilidade e arrisca elaborar ideias e teorias que possam ser efetivamente válidas e consideradas universalmente. Por essa razão é que ela se encontra sempre no terreno da possibilidade, da interrogação acerca de algo que deve ser também possa ser: "[...] postular sempre o que deve ser também pode ser... é dever do filósofo radical verificar se é possível o que deve ser e - ainda mais importante - como é possível". (HELLER, 1983, p. 154);

b) A Filosofia Radical, a história e a antropologia, embora diferentes, são conhecimentos interdependentes. Assim como não é possível uma filosofia sem história, também não é possível pensar a Filosofia Radical sem a tematização antropológica. Melhor dizendo, a Filosofia Radical, necessariamente, precisa perguntar se "[...] o homem empírico, a humanidade empírica, são capazes de realizar os ideais da utopia radical? (HELLER, 1983, p. 153). O recurso ao modo empírico de "olhar" e interrogar o "humano-social" e a própria "humanidade" é de natureza antropológica. Daí a possibilidade de uma filosofia social. Realizar os ideais da utopia radical significa, em outro sentido, pensar sobre os limites e possibilidades da elevação do homem particular (individual) à condição de "homem-genérico". O empírico, além do sentido antropológico, remete a filosofia à história na medida em que 
lhe propõe outra tarefa central: a de estabelecer, a partir do presente, um diagnóstico de época. A Filosofia Radical é uma filosofia de seu tempo, isto é, "[...] dotada de consciência histórica: por isso, deve investigar também a origem da estrutura social do presente. [...] deve refletir historicamente sobre si mesma, sem abandonar a pretensão à validade universal de seus ideais". (HELLER, 1983, p. 153);

c) Duas são as dimensões fundamentais que distinguem e dão identidade à Filosofia Radical quando comparada a outras formas filosóficas de pensar: a) a dimensão pensar-existir: a capacidade de prognosticar os problemas da existência e da vida humana procurando soluções plausíveis a partir de argumentações sistemáticas e rigorosas que tomam a ação humana como critério central; b) a dimensão do pensar-agir-viver: o extremo cuidado para não colocar entre parênteses a pergunta "como se deve viver" correndo o risco de não obter uma resposta a esse visível carecimento do ser humano na atualidade. Isto é, ser capaz de propor "[...] uma forma de vida em conformidade com a qual seja possivel viver a partir de hoje: viver na perspectiva de como se deve viver. A Filosofia Radical não pode se subtrair à realização da tarefa de dar uma resposta aos problemas existenciais da vida humana". (HELLER, 1983, p. 155). É nesse sentido a defesa de que a Filosofia Radical "quer que a terra se torne a pátria da humanidade". Eis porque ela não pode se afastar e nem omitir seu papel político-social de "[...] se tornar práxis para que a práxis se torne teórica, para que os homens possam se elevar ao nível da discussão filosófica, antes que seja tarde demais". (HELLER, 1983, p. 158).

\section{A recepção filosófica}

Trataremos aqui da questão central feita por Heller em relação às possíveis formas de apropriação filosófica, mais especificamente de como se dá a recepção filosófica. De modo um tanto esquemático, seguindo a tipografia por ela criada e desenvolvida, por meio da qual mostra as diversas possibilidades de apropriação filosófica.

Nesse sentido, antes de explicitarmos a análise dos tipos de recepção de Heller alertamos para a diferença existente entre recepção da filosofia e as abordagens especializadas da filosofia dos especialistas, que não são decorrentes do carecimento de filosofia, mas sim do puro interesse de investigação científica 
particular. A recepção da filosofia é decorrente do carecimento das objetivações filosóficas que "[...] incitam o receptor a refletir sobre o modo como deve pensar, como deve agir, como deve viver". (HELLER, 1983, p. 33).

Heller nos apresenta uma extensa divisão e subdivisões dos tipos de receptores da filosofia, que procuramos sumarizar a seguir, a fim de que este referencial possa contribuir com o aprofundamento das reflexões acerca do Método filosófico. Principalmente nos dias de hoje em que há uma vasta produção de informações e dados sobre educação filosófica - sem dúvida, importantes investigações do ponto de vista da construção de prognósticos -, mas que valorizam sobremaneira os procedimentos metodológicos técnicos de "como fazer/ensinar", enfatizando elementos formais, em detrimento dos aspectos substantivos do Método filosófico que encontra na indagação, na reflexão e na argumentação seu sentido essencial.

Podemos afirmar que a filósofa parte, em sentido amplo, de três horizontes teóricos: a) utopia racional (como se deve pensar, colocando a razão a serviço da solução dos problemas humanos reais, dos carecimentos); b) teoria social ou da sociedade (como se deve agir, considerando a necessidade de atender o carecimento de orientação por mudança social e construção de uma sociedade de novo tipo - antítese à forma de vida do capitalismo -, à luz do Bem e da Verdade); e c) filosofia da vida presente (como se deve viver, buscando responder como é possível viver a partir "do hoje", viver na perspectiva de como dar respostas aos problemas existenciais/sociais da vida humana).

A recepção pode acontecer de duas maneiras: a recepção completa ou total e a recepção incompleta ou parcial. Enquanto a recepção parcial corresponde a um dos momentos ou, de modo mais específico, à recepção de uma das perguntas: como se deve pensar, como se deve agir e como se deve viver. A recepção completa abarca, ao mesmo tempo, os três momentos da filosofia. A recepção parcial se concentra em apenas um momento e não consegue abarcar toda a filosofia, produzindo apenas resultados fragmentados, como podemos depreender nas palavras da própria autora:

Falamos de recepção completa para os tipos que compreendem ao mesmo tempo todos os três tipos da filosofia, refletes como deve pensar, agir e viver e de recepção parcial, para os que compreendem o primeiro, o segundo ou o terceiro momento. No primeiro caso, tem-se apropriação da objetivação filosófica, já que a intenção se dirige à objetivação. No segundo caso, a intenção não visa à objetivação filosófica, mas a recepção é o meio para produzir um outro efeito: desde a solução de problemas existenciais pessoais até a exposição de teorias em outras esferas. Veremos 
ainda que nem mesmo uma recepção preferencial, ou seja, parcial, ocorre isoladamente dos outros momentos. Há três tipos de recepção completa: a do receptor estético, a do entendedor e a do receptor filosófico propriamente dito. (HELLER, 1983, p. 35).

A recepção completa abarca, portanto, os três momentos da filosofia (como devo pensar, devo viver e agir?) e é classificada por Heller (1983) em três categorias:

\section{a) Receptor estético - apropriação por meio da forma}

A recepção estética da filosofia se dá pela apropriação da forma da obra filosófica, que é diferente da apropriação do sistema. Um sistema é composto por várias obras. O receptor busca na forma estética da obra de filosofia uma forma que se adeque à sua recepção estética. Toda filosofia é uma forma de vida e, ao apropriar-se da forma estética da obra, o receptor se apropria de sua concepção de mundo e a transforma em conceitos lógicos e, consequentemente, numa experiência de vida. O receptor estético é aquele que vê a obra filosófica como algo belo: por isso, a sua recepção será sempre catártica. Nele, a ideia não estimula, em primeiro lugar, outras ideias, mas sentimentos. "[...] Para ele, a recepção da forma significa: Encontrei! É assim que se deve pensar, agir, viver". (HELLER, 1983, p. 36).

Heller (1983) esclarece que "[...] de modo análogo pode ocorrer na recepção filosófica uma catarse negativa seguindo o esquema: Agora sei: posso ver que o todo não tem sentido". (HELLER, 1983, p. 36).

\section{b) Receptor entendedor - domínio da cultura filosófica}

Ao contrário do especialista em filosofia, o receptor entendedor tem um amplo domínio da cultura filosófica e a vê como parte orgânica da cultura. Ele busca compreender e interpretar os sistemas filosóficos admirando seu caráter de obra humana. "O entendedor formula um 'juízo de gosto’ filosófico; tem uma agudíssima sensibilidade para as diferenças entre as várias elaborações. Os entendedores formam o estável círculo dos que compreendem, julgam e leem filosofia”. (HELLER, 1983, p. 37).

\section{c) Receptor filosófico - apropriação do modus operandi filosófico}

Na compreensão de Heller, o receptor filosófico é o verdadeiro receptor da filosofia, pois, para se apropriar filosoficamente da filosofia, ele escolhe somente uma filosofia como utopia racional, uma forma de vida e decide viver coerentemente de acordo com aquela filosofia. O fundamento da recepção fi- 
losófica é a compreensão que se faz a partir da forma de vida do receptor, que é determinada pelos problemas da vida cotidiana. A recepção da filosofia pelo receptor é mediada pelas experiências vividas que decorrem de seu próprio mundo e de sua relação com ele.

Segundo a fórmula radical da Filosofia juvenil da arte de György Lukács, toda compreensão é um mal-entendido. Os sistemas filosóficos são infinitos, tal como as obras de arte. Por isso, as suas possibilidades de interpretação são também inesgotáveis. [...] uma compreensão pode contrapor-se a outra, mas sempre de modo a que ambas possam ser aceitas como compreensão que - como qualquer compreensão - contém o momento do mal-entendido. [...] "Toda compreensão é um mal-entendido" não implica, com efeito, que seja verdade o inverso. (HELLER, 1983, p. 38).

Esse caminho aberto por Heller possibilita, a nosso ver, depreender uma perspectiva teórico-metodológica inovadora para a recepção filosófica. No entanto, a autora faz um alerta sobre a diferença entre mal-entendido e ignorância, que consiste em qualquer interpretação que modifica os valores do sistema interpretado, ou que atribua a um filósofo frases que jamais pronunciou. O receptor filosófico sempre se objetiva e essa objetivação se funda sobre a mediação compreensiva/mal-entendedora entre o sistema filosófico escolhido e o presente concretamente determinado.

[...] há um único critério geral de separação para remediar os erros de fato, uma vez excluída a ignorância. É o mesmo que vale para toda a filosofia ou arte: quando o intérprete subverte ou muda a hierarquia de valor, estamos diante - claramente - de um mal-entendido. Mas, na medida em que os diversos intérpretes conservam-se presos à hierarquia de valor da filosofia de Marx, devemos qualificar toda compreensão com mal-entendidos dessa filosofia igualmente verdadeira compreensão. (HELLER, 1983, p. 143).

Uma compreensão de valor filosófico é circunscrita a determinadas classes, camadas, movimentos sociais, ou com seus interesses, necessidades e a escolha de uma filosofia evidencia essa afinidade. A recepção filosófica implica uma relação ativa com a filosofia, de modo que o receptor passe a vivenciá-la integralmente e desenvolva atitudes filosóficas, veja, pense e se comporte como filósofo. Dessa forma, o mal-entendido tem a função de levar a uma nova filosofia, a um 
novo sistema filosófico. O mal-entendido não é um erro por ignorância, e sim a fundação de um novo sistema filosófico.

Heller também divide a recepção filosófica parcial em três momentos da objetivação da utopia racional, ou seja, os elementos: reflete como deves pensar, deves agir e viver tem função isolada. Esse isolamento pode excluir a possibilidade do conhecimento de até mesmo de um único sistema filosófico. No entanto, tem seu valor uma vez que "[...] a apropriação de uma única obra e, inclusive, de uma parte de uma única obra, pode provocar o sentimento do 'eureka'. 'Ora, finalmente eu vejo!'”. (HELLER, 1983, p. 41).

Heller apresenta três possibilidades de recepção parcial: a) a recepção política; b) a recepção iluminadora; e c) a recepção guia do conhecimento.

\section{a) Recepção política - como se deve agir?}

A recepção política ocorre quando a recepção filosófica parcial é guiada unicamente pelo "reflete como deves agir". Nesse sentido, política significa toda a atividade dirigida à transformação da realidade social, e isso só é possível nas filosofias em que a utopia é também uma utopia social, em que está presente o confronto do dever-ser com o ser, fazendo brotar as consequências sociais esperadas ou almejadas. A filosofia, e especialmente a filosofia política, é uma utopia racional. Mas, se ela não for consciente disso, poderá transformar-se em ideologia por meio da recepção política.

A recepção ideológica não é nem compreensão nem mal-entendido, mas consiste em "extrair" do todo uma ou várias ideias, valores e formulações, em função da direção para a ação, ou melhor, da direção para o sucesso da ação. [...] Para o receptor ideológico, uma ideia filosófica, um valor ou um ideal representam efetivamente um "sinal", um símbolo, sob cuja proteção ele alcança a vitória e com o qual legitima suas vitórias e derrotas, sua atividade ou sua renúncia a ela. (HELLER, 1983, p. 44).

A proximidade entre a recepção política e a recepção ideológica é pequena e, às vezes, elas podem confundir-se na medida em que o receptor é guiado apenas pelo como se deve agir. O que as distingue é o caráter doutrinário da recepção ideológica que leva o receptor a uma ação política pontual, distanciando-se da utopia social, assumindo uma atitude proselitista.

\section{b) Recepção iluminadora - como se deve viver?}

$\mathrm{Na}$ recepção filosófica parcial iluminadora o receptor isola o momento do "como devo viver", ignorando o "como devo pensar" e "como devo agir". O que 
ele busca é apenas dar sentido à própria vida, não se importando com nenhuma generalização de forma de vida oferecida pela filosofia. É uma recepção sentimental, na qual o receptor busca na filosofia uma forma de iluminar o sentido existencial de sua vida, buscando respostas às perguntas, como, por exemplo, por que estou no mundo? Qual é minha missão neste mundo? São propícios à recepção iluminadora, por exemplo, o estoicismo e o epicurismo, ou filosofias que dão respostas às questões existenciais, especialmente as que dão pistas de como a vida deve ser vivida. O carecimento axiológico parece ser o que move os receptores na busca desse tipo de filosofia. Isso ocorre especialmente em momentos de crise dos valores.

Segundo a autora, essa crise manifesta-se sob dois aspectos. O primeiro é o da dissolução da comunidade caracterizada pela submissão de todos às normas. Isso faz com que não haja carecimento pessoal, pois tudo se resolve no âmbito da comunidade. E o segundo é o enfraquecimento dos princípios religiosos e, consequentemente, do sentimento religioso, fazendo com que as respostas, que antes a religião oferecia, já não sejam suficientes para enfrentar os desafios da própria vida. Ao buscar as respostas na filosofia, o receptor seleciona a parte dela que ilumina sua vida.

Assim, a recepção iluminadora visa satisfazer o carecimento religioso provocado pela crise das religiões tradicionais e não pode ser chamada nem de compreensão, muito menos de mal-entendido, pois não tem sentido algum afirmar que o receptor entendeu mal ou não entendeu, quando se deteve em apenas um pequeno fragmento de um sistema filosófico ou de um autor e disso depreendeu um ensinamento que iluminou sua vida, antes sem sentido. Todas as filosofias apresentam a possibilidade da recepção iluminadora, uma vez que é o receptor que seleciona e elege os aspectos de uma determinada filosofia a fim de satisfazer seu carecimento religioso.

\section{c) Recepção guia do conhecimento - como se deve pensar?}

A terceira forma de recepção parcial é, para Heller, um tipo de recepção na qual o receptor se apropria do momento "reflete como devo pensar" e o transforma em guia do conhecimento. Essa forma de recepção dá a possibilidade ao cientista, por exemplo, de apropriar-se da filosofia pelo carecimento produzido por sua tarefa científica. Nem todas as filosofias são adequadas a esse tipo de recepção, mas somente as que têm como centro a fundação do conhecimento ou sejam sistemas filosóficos abrangentes e tenham um estatuto diverso, quer se trate das ciências da natureza ou das ciências da sociedade. O que as ciências modernas buscam na filosofia é a emancipação por meio da construção de seu próprio método para sua realização prática. Especificamente no caso das ciências sociais, essas buscam na filosofia uma hierarquia de valores por meio de uma “recepção avaliativo-cognoscitiva". (HELLER, 1983, p. 50). 
Em primeiro lugar, porque certamente, ao procederem assim, dão um passo em direção à desfetichização das teorias da sociedade, ou seja, abstraem-se do sistema de preconceitos da consciência cotidiana. Desse modo, o momento do "espanto" - o questionamento do que aparece óbvio - adquire espaço também no pensamento teórico-social. Em segundo lugar, porque - depois da escolha consciente de valores e do compromisso com eles - torna-se possível uma discussão de valor entre os sistemas teóricos, discussão através da qual, pelo menos, podem ser evitados os obstáculos representados pelos debates de valor cotidianos. E, em terceiro lugar, porque uma recepção avaliativo-cognoscitiva pode abrir caminho para a recepção completa de filosofias. Trata-se, contudo, de um pressuposto para que filosofia e teoria da sociedade voltem a se encontrar. (HELLER, 1983, p. 51).

A filosofia, em certa medida, assume o papel de aglutinadora das demandas das ciências da natureza e das ciências sociais por conta das necessidades originadas no interior da atividade científica dessas ciências, quando o cientista se coloca o imperativo de buscar na filosofia a fundamentação e revisão de suas teorias, bem como a estruturação e crítica do método.

\section{Conclusão}

Diante do exposto, pode-se concluir que para compreender o sentido da Filosofia Radical é necessário primeiro entender que ela é, sim, filosofia com nome próprio e, por conseguinte, não é autoajuda, nem "livre pensar". Que, embora também não seja filologia, nem história, nem antropologia, ela não existe sem esses conhecimentos. E, mais, não pode ser compreendida, no limite, como uma área do conhecimento, pois se a Filosofia Radical assim for entendida ela será "apenas" filosofia ou simplesmente mais uma filosofia, um sistema filosófico ou ainda uma importante parte da História da Filosofia.

A Filosofia Radical, ao contrário das filosofias, tem uma função central que é assegurar o caminho que leva do parcial ao geral, do indivíduo particular ao humano-genérico, da racionalidade do intelecto à utopia racional. Nesse sentido, ela é filosofia do presente, isto é, precisa responder como é possível viver o presente na perspectiva de como se deve viver, de como dar respostas aos problemas existenciais e sociais da vida humana. Por isso, não se trata de 
um mero pensar sistemático e rigoroso (próprio da natureza de toda filosofia) ou de uma forma de conhecimento e método para bem conduzir a razão.

Sua razão de ser pode ser definida pela sua função social: orientação para vida. Assim compreendida, ela se preserva no horizonte da utopia racional procurando responder questionamentos como: Para onde conduzir a sociedade? Como colocar a razão a serviço da solução dos problemas e carecimentos humano-sociais? Como elaborar uma teoria crítica da sociedade como antítese à forma de vida do capitalismo?

O Método filosófico passa pelo modo como se dá a recepção: parcial ou total. Toda recepção tem sua importância e valor uma vez que abarca de alguma forma as perguntas: como se deve pensar? Como se deve agir? Como se deve viver? A Filosofia Radical se identifica essencialmente com a recepção completa na medida em que corresponde aos três momentos da apropriação filosófica. Tanto o receptor "estético" (que se apropria da obra filosófica por meio da forma), quanto o receptor "entendedor" (que se apropria da filosofia como parte orgânica da cultura), bem como o receptor "filosófico" (que se apropria filosoficamente da filosofia, como compreensão - mal-entendido - e forma de vida), podem ser considerados receptores completos, no entanto, o receptor "filosófico" é considerado por Heller o receptor por excelência. Funda-se no "verstehen", no sentido pleno e forte da utopia racional.

\section{REFERÊNCIAS}

BITTENCOURT GRANJO, M. H. Agnes Heller: Filosofia, Moral e Educação. Petrópolis: Vozes, 1996.

HELlER, A. A Filosofia Radical. Tradução de: COUTINHO, C. N. São Paulo: Brasiliense, 1983.

HELLER, A. Sociología de la vida cotidiana. Barcelona: Ediciones Península, 2002.

HELLER, A. O Cotidiano e a História. Tradução de: COUTINHO, C. N.; KONDER, L. 7. ed. São Paulo: Paz e Terra, 2004.

Texto recebido em 18 de janeiro de 2016.

Texto aprovado em 17 de maio de 2016. 
